\title{
KOMUNIKASI ADVOKASI KLARIFIKASI FAKTA PEMBERITAAN HOAKS PADA INSTAGRAM @JALAHOAKS
}

\author{
Danang Wiryawan $^{1 *}$, Rini Riyantini², dan Lusia Handayani ${ }^{3}$ \\ 1,2,3 Universitas Pembangunan Nasional Veteran Jakarta, Jakarta, Indonesia \\ *masdanangwn@gmail.com
}

\begin{abstract}
Problems regarding the widespread spread of hoax news often occur through social media. The massive circulation of hoaxes that occurs is due to the low level of digital literacy in the community in filtering information that can potentially disturb the public and disrupt public order. Government public bodies are considered to have the responsibility to eradicate social problems related to the circulation of hoax news that occurs in the community. This prompted the DKI Jakarta Provincial Government of Communication, Information and Statistics to create the Jakarta Lawan Hoaks (Jalahoaks) channel to carry out advocacy activities. This study aims to analyze the advocacy communication process for truth clarification on hoax news on Instagram @ Jalahoaks. This research uses a qualitative approach with exploratory research and case study methods. The theory used in this research is advocacy communication. The results of this study indicate that the advocacy communication process carried out on Instagram @ Jalahoaks can be successful and run effectively, based on analysis, strategy, mobilization, action, evaluation, and sustainability. The use and maximization of Instagram social media as a means to clarify the facts of hoax news can support and facilitate the advocacy communication process carried out by Jalahoaks.
\end{abstract}

Keywords: Advocacy Communication; Hoax News; Instagram Social Media

\begin{abstract}
Abstrak
Permasalahan mengenai maraknya penyebaran berita hoaks banyak terjadi melalui media sosial. Masifnya peredaran hoaks yang terjadi disebabkan karena rendahnya tingkat literasi digital di masyarakat dalam menyaring suatu informasi yang dapat berpotensi meresahkan masyarakat dan mengganggu ketertiban di publik. Badan publik pemerintahan dianggap memiliki tanggung jawab untuk mengentaskan permasalahan sosial terkait dengan beredarnya berita hoaks yang terjadi di masyarakat. Hal tersebut mendorong Dinas Komunikasi, Informatika dan Statistik Pemprov DKI Jakarta membuat kanal Jakarta Lawan Hoaks (Jalahoaks) untuk melakukan upaya kegiatan advokasi. Penelitian ini bertujuan untuk menganalisis proses komunikasi advokasi klarifikasi fakta pemberitaan hoaks pada Instagram @Jalahoaks. Penelitian ini menggunakan pendekatan kualitatif dengan jenis penelitian eksploratif dan metode studi kasus. Teori yang digunakan dalam penelitian ini adalah komunikasi advokasi. Hasil penelitian ini menunjukkan bahwa proses komunikasi advokasi yang dilakukan pada Instagram @ Jalahoaks agar dapat berhasil dan berjalan efektif, berdasarkan analisis, strategi, mobilisasi, aksi, evaluasi, dan kesinambungan. Penggunaan dan pemaksimalan media sosial Instagram sebagai sarana dalam melangsungkan klarifikasi fakta pemberitaan hoaks dapat menunjang dan mempermudah proses komunikasi advokasi yang dijalankan oleh Jalahoaks.
\end{abstract}

Kata Kunci: Komunikasi Advokasi; Media Sosial Instagram; Pemberitaan Hoaks

\section{PENDAHULUAN}

Di Indonesia terdapat paling banyak temuan penyebaran berita hoaks di media sosial Facebook sebesar 84\% (CIGI-IPSOS, 2019). Sebanyak 56,55\% informasi hoaks ditemukan dari Whatsapp dan di Instagram sebanyak 29,48\% (DailySocial \& Jakpat Mobile Survey
Platform, 2018). Sebesar $41 \%$ masyarakat Indonesia memeriksa dan mengklarifikasi pemberitaan hoaks yang ditemukan menggunakan situs berita fact-checking, yang berarti sebesar 59\% lainnya tidak memeriksa kembali berita yang ditemukan dan dapat berpotensi hoaks (CIGI-IPSOS, 2019). 
Penyebaran berita hoaks di media sosial adalah saluran penyebaran terbesar, sedangkan yang kedua adalah aplikasi chatting (Septanto, 2018).

Tingkat persentase yang menyatakan bahwa masyarakat tidak selalu mengetahui apakah berita yang didapatkan mereka termasuk hoaks atau bukan sebesar 56,4\%. Sebanyak $55,8 \%$ masyarakat tidak memeriksa kembali tentang kebenaran suatu berita karena mengira sudah ada yang memeriksanya. Selain itu, sebesar $63,3 \%$ masyarakat mengira bahwa berita yang ditemukannya bukan termasuk berita hoaks karena mereka mendapatkan berita tersebut dari orang yang dipercaya. Selanjutnya, tingkat intensitas masyarakat dalam menerima berita hoaks per harinya sebesar 34,6\%. Maka dari itu, sebanyak $61,5 \%$ masyarakat merasa sangat terganggu dengan keberadaan berita hoaks di media sosial. Masyarakat sangat setuju bahwa berita hoaks juga dapat berdampak terhadap aspek sosial, sebanyak 81,9\% menganggap hoaks dapat menggangu kerukunan di masyarakat dan sebanyak $76,4 \%$ berpendapat bahwa hoaks dapat menghambat pembangunan. Oleh karena itu, sebesar 59,1\% masyarakat menilai penanggulangan hoaks menjadi tanggung jawab dari pemerintah (Mastel, 2019). Kehadiran berita hoaks/bohong dapat bertujuan untuk mendiskreditkan individu ataupun kelompok tertentu (Musfah, 2018).

Dalam suatu studi, para psikolog bersepakat bahwa berita hoaks dapat berdampak buruk pada kesehatan mental, seperti kecemasan, stres, kekerasan, kepanikan, sampai PTSD (Post Traumatic Stress Disorder). Berita hoaks dapat menimbulkan perasaan marah bahkan depresi (Pozios, 2018). Hal tersebut karena berita hoaks bertujuan untuk memanipulasi opini dan mendistorsi pemikiran publik, sehingga dapat menimbulkan respon yang emosional dari masyarakat.

Tingkat literasi digital di Indonesia masih belum dapat dikatakan tinggi, hal ini seiring dengan kemampuan masyarakat dalam mengenali hoaks yang rendah. Indeks literasi digital nasional berada di angka 3,47 yang berarti sedikit di atas level "menengah" dan belum mencapai level "baik" (Katadata Insight
Center, 2020). Kemampuan literasi media yang baik dapat memengaruhi perubahan perilaku masyarakat (Herawati et al, 2019).

Tahun 2020 laporan mengenai berita hoaks di DKI Jakarta tiap bulannya bervariasi jumlahnya, berkisar mulai dari 45 aduan berita hoaks sampai dengan yang paling banyak 320 aduan berita hoaks dengan tingkat klarifikasi 94\% sampai $100 \%$. Total persentase klarifikasi hoaks sebesar $100 \%$ artinya adalah semua laporan berita hoaks yang diadukan oleh masyarakat dapat berhasil diklarifikasikan faktanya atas kebenaran dari berita hoaks tersebut. Sedangkan, tingkat klarifikasi yang hanya mencapai sebesar $94 \%$ atau kurang dari $100 \%$ artinya adalah tidak semua laporan berita yang diadukan oleh masyarakat dapat berhasil diklarifikasi. Hal tersebut dapat terjadi karena adanya kemungkinan aduan hoaks tersebut tidak memenuhi syarat atau masih dalam proses verifikasi. Sepanjang tahun 2020 sudah tercatat sebanyak 1.078 aduan kasus berita hoaks di DKI Jakarta yang dilaporkan oleh masyarakat (Jalahoaks, 2020). Dibutuhkan pelibatan peran individu, masyarakat, organisasi, maupun lembaga nasional untuk membantu pencegahan penyebaran berita hoaks di media sosial (Siswoko, 2017).

Di Indonesia terdapat beberapa instansi/organisasi yang juga bertugas dalam menjalankan klarifikasi berita hoaks seperti misalnya, Kementerian Komunikasi dan Informatika (Kemkominfo), Turn Back Hoax, dan Masyarakat Anti Fitnah Indonesia (Mafindo). Kemkominfo berupaya dengan proaktif dalam melakukan klarifikasi berita hoaks yang beredar di media sosial dengan cara mengidentifikasi dan meyusun klarifikasi atas berita hoaks yang tersebar di masyarakat serta menyebarluaskan informasi penyeimbang (Kemkominfo, 2020). Sedangkan, Turn Back Hoax melakukan klarifikasi hoaks dengan cara menelusuri melalui media sosial yang kemudian dianalisis serta dirangkum dan diarsipkan, lalu dipublikasikan temuan berita hoaks tersebut (Kemkominfo, 2017). Selain itu, Mafindo menjalankan klarifikasi hoaks melalui pemantauan di internet atas penyebaran 
disinformasi/misinformasi yang ada untuk diperiksa faktanya dan kemudian diunggah hasilnya di forum media sosial (Mafindo, 2021)

Keunikan dan perbedaan yang dilakukan dan dimiliki oleh Jalahoaks dengan yang lainnya dalam klarifikasi berita hoaks adalah Jalahoaks melakukan klarifikasi dengan berdasarkan laporan aduan hoaks dari masyarakat sehingga mengedepankan partisipasi yang aktif dari publik dalam melangsungkan kegiatan advokasi. Selain itu, Jalahoaks terbilang rutin menyebarkan informasi mengenai hasil dari berita hoaks yang sudah terklarifikasi faktanya di media sosial Instagram sehingga aktivitas advokasi yang dilakukan berlangsung secara intens kepada publik. Klarifikasi hoaks yang dilakukan oleh Jalahoaks dengan cara memantau dan menerima laporan, melaksanakan klarifikasi fakta, serta mengedukasi masyarakat melalui literasi digital.

Upaya kerjasama antar pemangku jabatan dalam hal ini adalah instansi pemerintah sebagai badan publik merupakan hal yang penting dalam mengatasi persoalan fenomena hoaks yang terjadi (Munzaimah dan Lubis, 2020). Advokasi sebagai istilah kunci dalam wacana pembangunan yang bertujuan untuk memunculkan kebijakan publik yang mencarikan solusi atas suatu permasalahan (Servaes dan Malikhao, 2012).

Media sosial berperan aktif dalam memperlebar jangkauan pemanfaatan advokasi melalui media online (Simamora, 2017). Media sosial merupakan perkembangan mutakhir dari teknologi perkembangan web baru berbasis internet, yang memudahkan semua orang untuk dapat berkomunikasi, saling berbagi, dan berpartisipasi (Zarella, 2010). Instagram merupakan platform media sosial yang paling aktif digunakan sebesar 79\% (Hootsuite-We Are Social, 2020).

Sebanyak 60,39\% masyarakat di DKI Jakarta merupakan pengguna Instagram. Selain itu, tingkat pengetahuan masyarakat terhadap media sosial milik Pemprov DKI Jakarta sebesar $52,7 \%$ Intensitas kunjungan masyarakat terhadap Instagram milik Pemprov DKI Jakarta sebanyak 43,75\%. Dan, sebesar 77,06\% masyarakat menilai bahwa media sosial milik Pemprov DKI Jakarta memberikan kemudahan dalam mengakses/mendapatkan informasi (Diskominfotik, 2019).

Atas dasar permasalahan sosial mengenai maraknya penyebaran pemberitaan hoaks melalui media sosial yang terjadi di masyarakat, membuat Dinas Komunikasi, Informatika dan Statistik (Diskominfotik) Pemprov DKI Jakarta selaku badan publik pemerintahan memiliki tanggung jawab untuk mengentaskan permasalahan tersebut untuk menjaga ketertiban di masyarakat serta melanjutkan program pembangunan.

Diskominfotik Pemprov DKI Jakarta membuat kanal "Jakarta Lawan Hoax" (Jalahoaks), kanal ini dibuat untuk memberikan literasi digital kepada khususnya masyarakat DKI Jakarta agar bersama-sama melawan hoaks dan selalu menyebarkan konten positif dan bermanfaat di media sosial. Selain itu juga bertujuan untuk memerangi pencegahan informasi palsu yang beredar di masyarakat yang dapat berpotensi meresahkan masyarakat. Kanal Jalahoaks mulai beroperasi pada 19 Maret 2020 dan dikelola oleh Seksi Pelayanan Informasi Publik, di bawah naungan Bidang Informasi Publik, Diskominfotik Pemprov DKI Jakarta (Berita Jakarta, 2020).

Dalam melangsungkan kegiatan advokasi pemberitaan hoaks, Jalahoaks menggunakan media sosial Instagram. Instagram @ Jalahoaks merupakan media informasi dan klarifikasi fakta pemberitaan yang beredar di masyarakat melalui media sosial dengan memanfaatkan teknologi informasi untuk melaksanakan pengelolaan informasi publik yang sehat dan positif. Tujuan dari adanya Instagram @Jalahoaks adalah untuk memantau dan menerima pengaduan informasi dan selanjutnya klarifikasi fakta terhadap laporan yang diterima kemudian disosialisasikan melalui media sosial atas kebenaran berita/informasi yang sesungguhnya. Dalam mengupayakan sosialisasi kepada masyarakat DKI Jakarta terkait dengan beredarnya pemberitaan hoaks di media sosial yang semakin banyak dan menjadi permasalahan sosial, masyarakat dapat 
memberikan pengaduan atas kevalidan berita atau informasi yang diterima dari media sosial.

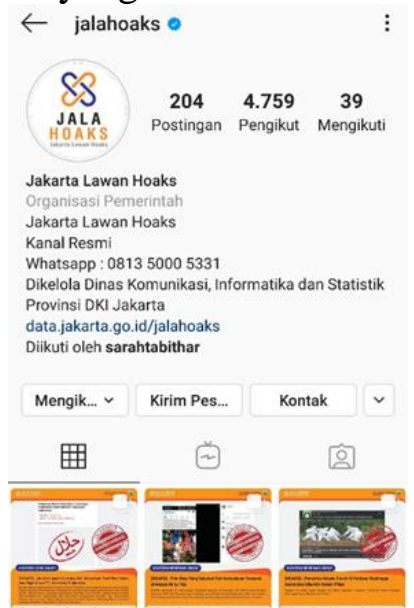

Gambar 1. Tampilan Instagram @Jalahoaks (sumber : Instagram @ Jalahoaks, 2021)

Dalam penelitian ini teori yang digunakan adalah teori advokasi yang pertama kali diperkenalkan oleh Center for Communication Programs (CCP) Johns Hopkins University (1988). Teori ini bergerak dalam bidang komunikasi strategis untuk masyarakat dalam membangun dan menerapkan konsep dan teknologi baru untuk mengevaluasi kaitan antara promosi dan advokasi dengan perubahan perilaku. Teori ini dapat digunakan pada lembaga pemerintah di tingkat lokal dan nasional.

Teori advokasi ini menjelaskan usaha untuk memengaruhi kebijakan publik melalui berbagai macam bentuk komunikasi persuasif yang bertujuan untuk mengendalikan perilaku individu, masyarakat, dan lembaga. Teori ini bermanfaat dalam memahami tentang berbagai upaya advokasi terhadap permasalahan yang ada.

Advokasi melibatkan komunikasi publik untuk mendukung tujuan tertentu. Proses tersebut melibatkan berbagai khalayak, komunitas, dan juga pembuat kebijakan (pemerintah) untuk mendapatkan suatu dukungan sosial. Proses komunikasi dalam advokasi bersifat strategis dengan bidang komunikasi pembangunan yang meluas dan perubahan sosial di dalamnya serta dikonseptualisasikan dan diimplementasikan untuk kepentingan publik/umum.
Komunikasi advokasi menawarkan pendekatan kritis dalam bidang pembangunan. Peran komunikasi dapat memfasilitasi dan membatasi potensi dari advokasi. Komunikasi itu sendiri menawarkan proses dan konteks untuk advokasi. Advokasi telah dikonseptualisasikan dalam bidang pembangunan dan perubahan sosial. Advokasi berfokus pada mempertimbangkan nilai potensial dari perubahan sosial.

Komunikasi advokasi dibangun di atas pemahaman komunikasi sebagai proses sosiokultural dari pertukaran simbolik. Wacana advokasi membantu menyampaikan gagasan bahwa komunikasi dapat mewakili kesepakatan bersama. Komunikasi advokasi dibutuhkan dalam pelayanan advokasi. Komunikasi dapat digunakan dalam memfasilitasi advokasi untuk menemukan dan memahami suatu masalah serta solusi potensial bagi pihak-pihak yang terlibat. Advokasi menganggap komunikasi sebagai alat untuk mengubah psikologi atau perilaku individu.

Model perencanaan komunikasi untuk advokasi yang efektif dan supaya kegiatan advokasi dapat berhasil, maka terdapat enam tahapan/komponen perencanaan komunikasi yang dipenuhi, antara lain : (1) Analisis, analisis merupakan langkah pertama untuk melaksanakan advokasi yang efektif. Mencari informasi yang akurat terhadap permasalahan yang ada serta pemahaman mengenai permasalahan tersebut. Melihat masyarakat yang terlibat, organisasi, kebijakan serta keberadaannya, dan jalur yang dapat memengaruhi pengambilan keputusan, (2) Strategi, setiap kegiatan advokasi yang dilakukan memerlukan strategi. Tahapan strategi dibangun berdasarkan perencanaan, analisis yang mengarah, dan fokus pada tujuan khusus. Menentukan sasaran dan tujuan yang jelas dalam mencapainya, (3) Mobilisasi, memperkuat advokasi dengan kegiatan, peristiwa, materi, dan pesan pendukung berdasarkan sumber yang ada serta sesuai dengan tujuan sasaran kelompok. Mobilisasi harus memberi dampak positif yang maksimal bagi pembuat kebijakan dan membutuhkan 
partisipasi dari semua anggota, (4) Aksi, mempertahankan kegiatan dengan pengulangan pesan yang menggunakan alat bantu yang kredibel dengan tujuan mendapat perhatian dari isu yang ada, (5) Evaluasi, usaha advokasi harus dievaluasi secara seksama. Monitoring secara rutin dan objektif atas hasil sosialisasi yang dicapai dan apa yang masih harus dilaksanakan, dan (6) Kesinambungan, advokasi berlangsung secara terus menerus, mempertahankan fungsi, memperjelas tujuan jangka panjang, memantau perubahan yang terjadi, dan menyesuaikan data yang ada seiring dengan perubahan yang terjadi. Dengan terpenuhinya keenam tahapan tersebut diharapkan kegiatan advokasi yang dilakukan dapat dengan baik terlaksana.

Advokasi publik adalah penggunaan strategi komunikasi untuk memengaruhi perubahan sikap dan opini publik, sehingga dapat memengaruhi pengambil keputusan atau pembuat kebijakan dan mempromosikan norma sosial, perubahan perilaku, alokasi sumber daya, dan kebijakan untuk manfaat kelompok, komunitas, organisasi, atau populasi (Schiavo, 2014). Advokasi adalah aksi strategis yang ditujukan untuk menciptakan kebijakan publik yang dapat bermanfaat bagi masyarakat atau mencegah timbulnya kebijakan yang diperkirakan dapat merugikan masyarakat. Advokasi secara luas dipahami sebagai upaya sistematik dan terorganisasi untuk memengaruhi dan mendesakkan terjadinya perubahan kebijakan publik dalam masyarakat (Reyes, 1997). Edukasi berbalut hiburan adalah strategi untuk melengkapi pendekatan perubahan perilaku individu untuk pengadvokasian dengan tujuan perubahan sosial dan menemukan solusi. Advokasi komunikasi melibatkan strategis posisi politik yang jelas, bersifat netral, dan menghargai keadilan (Tufte, 2012).

Klarifikasi adalah penjelasan, pengertian, dan pengembalian kepada hal yang sebenarnya (Yuwono dan Silvita, 2009). Sedangkan, fakta adalah hal (peristiwa/keadaan) yang merupakan kenyataan, sesuatu yang benar terjadi (Santoso, 2001). Dapat disimpulkan bahwa klarifikasi fakta adalah usaha pengecekan untuk pencarian penjelasan terhadap informasi/berita yang benar-benar ada atau sesuai dengan kenyataan/peristiwa yang terjadi dan dapat dipertanggungjawabkan.

Hoaks adalah berita/informasi yang berisikan hal yang belum pasti atau bukan merupakan fakta yang sebenarnya terjadi (Juditha, 2018). Menurut David Harley (2008), terdapat karakteristik dalam berita/informasi hoaks, seperti : (1) Informasi hoaks biasanya berbentuk pesan berantai, (2) Tidak memiliki tanggapan yang realistis, (3) Tidak mempunyai tanggal kadaluarsa, dan (4) Tidak adanya kelompok atau organisasi yang diidentifikasi sebagai sumber informasi.

Media sosial merupakan sarana bagi konsumen untuk berbagi gambar, teks, video, dan audio dengan satu sama lain dan dengan perusahaan dan sebaliknya (Kotler dan Keller, 2012). Instagram ialah aplikasi berbagi foto yang memungkingkan pengguna mengambil foto, menerapkan filter digital, dan membagikannya ke berbagai layanan jejaring sosial, termasuk milik Instagram sendiri (Atmoko, 2012). Dengan hadirnya Instagram @Jalahoaks diharapkan dapat memberikan kemudahan bagi masyarakat DKI Jakarta dalam melakukan advokasi dan mengetahui mengenai berita/informasi hoaks yang diterima dari media sosial.

Berdasarkan hasil penelitian terdahulu Christanty (2020) meneliti tentang media sosial sebagai alat advokasi publik dan terdapat hasil kegiatan advokasi kebijakan publik melalui media sosial dapat menarik perhatian serta mempermudah masyarakat dalam menyampaikan aspirasi mengenai penetapan kebijakan yang dilakukan pemerintah. Sedangkan, Yanti dan Rusdi (2018) meneliti tentang pengaruh berita hoaks terhadap persepsi pembaca media online yang menjelaskan bahwa terpaan informasi hoaks di media online dapat memengaruhi persepsi pembaca dan membuat masyarakat menjadi lebih berhati-hati dengan pemberitaan hoaks yang ada. Siswoko (2017) meneliti kebijakan pemerintah dalam menangkal pemberitaan hoaks yang menunjukkan usaha pemerintah dalam memblokir website penyebar hoaks tidak terlalu 
efektif untuk membendung masifnya penyebaran berita hoaks. Berbeda dengan penelitian sebelumnya, penelitian ini akan berfokus pada upaya komunikasi advokasi yang dilakukan pada media sosial Instagram mengenai maraknya pemberitaan hoaks yang ada di masyarakat.

Penelitian ini bertujuan untuk menganalisis proses komunikasi advokasi klarifikasi fakta pemberitaan hoaks pada Instagram @Jalahoaks. Rumusan masalah dalam penelitian ini adalah bagaimana proses komunikasi advokasi Instagram @Jalahoaks Diskominfotik DKI Jakarta dalam klarifikasi fakta pemberitaan hoaks yang beredar di masyarakat?

Maka dari itu dibuatkanlah penelitian mengenai "Komunikasi Advokasi Klarifikasi Fakta Pemberitaan Hoaks Pada Instagram @Jalahoaks".

\section{METODOLOGI PENELITIAN}

Penelitian ini menggunakan pendekatan kualitatif karena penelitian ini mengumpulkan data lapangan yang didapatkan melalui wawancara mendalam atau indepth interview dengan narasumber atau informan yang sesuai dengan kebutuhan penelitian. Pendekatan penelitian kualitatif dilakukan dengan cara observasi atau mengamati objek penelitian yang diteliti secara langsung. Penggunaan pendekatan penelitian kualitatif pada penelitian ini adalah berfokus untuk menganalisis kegiatan proses komunikasi advokasi klarifikasi fakta mengenai pemberitaan hoaks melalui media sosial Instagram @ Jalahoaks.

Metode penelitian yang digunakan dalam penelitian ini adalah studi kasus. Metode penelitian studi kasus terfokus pada suatu kasus tertentu untuk dianalisis dan diamati secara multi perspektif. Studi kasus digambarkan sebagai proses pencarian data yang empiris untuk meneliti suatu kasus dalam kehidupan sosial. Penggunaan jenis penelitian studi kasus adalah untuk meneliti secara mendalam mengenai proses komunikasi advokasi mengenai pemberitaan hoaks pada Instagram kepada masyarakat luas.
Jenis penelitian yang digunakan adalah jenis penelitian eksploratif. Jenis penelitian eksploratif digunakan untuk menggali secara luas mengenai sebab atau hal yang memengaruhi terjadinya sesuatu/peristiwa. Peneliti menganalisis kegiatan/proses komunikasi advokasi yang dilakukan oleh Instagram@Jalahoaks dalam klarifikasi fakta pemberitaan hoaks.

Teknik yang digunakan dalam pengumpulan data untuk keperluan penelitian ini melalui wawancara mendalam dan observasi untuk memperoleh data yang meliputi proses komunikasi advokasi Instagram @Jalahoaks Diskominfotik DKI Jakarta dalam klarifikasi fakta pemberitaan hoaks yang beredar di masyarakat

Peneliti memberikan pertanyaan dalam bentuk pedoman wawancara secara terstruktur dan mendalam. Sebelum melakukan wawancara, peneliti mengajukan surat permohonan riset kepada Dinas Komunikasi, Informatika dan Statistik Provinsi DKI Jakarta. Peneliti juga memberikan lembar penjelasan penelitian dan lembar persetujuan dari informan untuk menjadi partisipan dalam penelitian ini. Peneliti melakukan proses wawancara dengan ketiga informan secara daring melalui Zoom Meeting Apps dan Google Meet dikarenakan situasi pandemi Covid-19 di DKI Jakarta.

Informan dalam penelitian ini berjumlah tiga orang, yang terdiri dari dua orang merupakan pejabat/karyawan dari Diskominfotik Pemprov DKI Jakarta serta anggota/tim Jakarta Lawan Hoaks (Jalahoaks) yang menjabat sebagai Kepala Seksi Pelayanan Informasi Publik, Diskominfotik Pemprov DKI Jakarta dan admin media sosial Instagram @ Jalahoaks, serta satu orang lainnya merupakan masyarakat umum/followers akun Instagram @Jalahoaks yang sudah pernah melakukan pengaduan pemberitaan hoaks yang didapat kepada Jalahoaks.

Dalam penelitian ini menggunakan teknik analisis data Robert K. Yin (2011), yang di dalamnya terdapat lima tahapan, yaitu compiling, disassembling, reassembling and arraying, interpreting, dan concluding. Adapun 
alur teknik analisis data sebagai berikut: Peneliti mengumpulkan seluruh data informasi yang diperoleh dari hasil observasi dan wawancara mendalam. Data-data tersebut dirapihkan berdasarkan aturan tertentu. Kemudian, seluruh data yang telah dirapihkan selanjutnya dipisahkan ke dalam bagian/kelompok yang lebih kecil untuk melakukan pemberian kode. Selanjutnya, peneliti menyusun ulang data dari bagian kecil yang terpencar dan mengelompokkannya ke dalam bagian/kelompok data yang lebih besar. Setelah itu, data yang telah dikumpulkan dan ditata selanjutnya disusun ke dalam bentuk naratif untuk diinterpretasikan dan disajikan. Terakhir, data yang telah terkumpul selanjutnya diambil/ditarik kesimpulan yang berdasarkan pada hasil interpretasi.

Dalam penelitian ini menggunakan teknik keabsahan data dengan menggunakan triangulasi data. Triangulasi data adalah bentuk triangulasi untuk menguji kredibilitas dengan menggunakan cara mengecek data kepada sumber yang sama tetapi dengan teknik yang berbeda. Triangulasi data dilakukan dengan cara berdiskusi dengan tujuan memastikan data yang dianggap benar dari sudut pandang/perspektif yang berbeda. Triangulasi data diperoleh melalui wawancara mendalam, setelahnya dicek dengan cara observasi objek yang diteliti, agar mendapatkan data yang dianggap benar.

\section{HASIL DAN PEMBAHASAN}

\section{Proses Komunikasi Advokasi Instagram @Jalahoaks Dalam Klarifikasi Fakta Pemberitaan Hoaks}

Hasil penelitian ini digambarkan berdasarkan rumusan pertanyaan penelitian, fokus, dan tujuan penelitian yang akan menyajikan proses komunikasi advokasi klarifikasi fakta pemberitaan hoaks pada Instagram @ Jalahoaks.

Ketiga informan dalam penelitian ini menjelaskan bagaimana proses komunikasi advokasi yang dilakukan oleh Diskominfotik Pemprov DKI Jakarta melalui Instagram @ Jalahoaks dalam klarifikasi fakta pemberitaan hoaks yang beredar di masyarakat. Terdapat enam tahapan dalam melakukan advokasi yang efektif dan supaya kegiatan advokasi yang dijalankan dapat berhasil, yaitu analisis, strategi, mobilisasi, aksi, evaluasi, dan kesinambungan.

Informan 1 mengungkapkan bahwa sebelum melakukan kegiatan komunikasi advokasi, dilakukannya rapat koordinasi internal Jalahoaks terlebih dahulu untuk merencanakan langkah-langkah dalam menjalankan pengelolaan laporan berita hoaks yang disampaikan oleh masyarakat, "Pertama untuk perencanaan terkait dengan pengelolaan Jalahoaks ini kita ada rapat koordinasi, ketika misalnya ada aduan/laporan yang masuk dari masyarakat terkait dengan hoaks ataupun informasi yang salah".

Informan 1 memberikan gambaran mengenai bahaya dan motif dari penyebaran hoaks yang ada di masyarakat, "Hoaks ini dianggap sebagai alat yang dapat digunakan untuk memengaruhi opini publik ataupun opini di masyarakat".

Informan 1 mengungkapkan Jalahoaks mempunyai dan membuka berbagai macam kanal pengaduan di media sosial supaya mempermudah masyarakat yang ingin melaporkan temuan berita hoaks-nya, "Karena juga melihat kondisi pandemi saat ini lebih efektif untuk masyarakat DKI Jakarta melalui media online untuk menjangkau dan mempermudah mereka dalam melakukan pengaduan ataupun advokasi".

Pada tahap strategi diungkapkan oleh informan 2 bahwa strategi yang dilakukan oleh Jalahoaks dengan selalu aktif memantau situasi, "Strateginya kita selalu memantau dan menerima laporan hoaks yang beredar di masyarakat. Lalu, kita melakukan klarifikasi fakta atas pengaduan yang diterima. Setelah itu, pada ujungnya kita juga melakukan edukasi dalam bentuk literasi digital kepada masyarakat".

Informan 1 mengungkapkan Jalahoaks berfokus pada maraknya peredaran berita hoaks yang terjadi di masyarakat, "Fokus kita adalah maraknya peredaran informasi yang salah atau memang sengaja dibuat salah yang disebar 
melalui media online ataupun perangkat digital".

Informan 1 menjelaskan Jalahoaks memiliki target yang ingin dicapai dari dilakukannya komunikasi advokasi ini, "Target dan tujuan kita adalah melakukan klarifikasi ataupun memberikan informasi kepada publik terkait informasi yang benar. Selain itu, juga meliterasi dan mengedukasi masyarakat mengenai informasi yang salah yang memang perlu dihindari oleh masyarakat untuk disebarkan".

Tahap ketiga, yaitu mobilisasi diungkapkan oleh informan 2 bahwa pesan yang disampaikan terhadap berita yang telah terklarifikasi faktanya dengan melakukan kategorisasi disinformasi, "Materi pesan yang digunakan adalah dengan cara memberikan informasi mengenai aduan pemberitaan hoaks yang telah diklarifikasi ke dalam kategori fakta atau jenis-jenis disinformasi yang ada".

Menurut pengalaman Informan 3 terdapat manfaat positif yang dirasakan setelah melakukan pengaduan pemberitaan hoaks ke Jalahoaks, "Untuk keuntungan dan manfaatnya sendiri setelah saya melakukan pengaduan kepada Jalahoaks, saya dapat mengetahui berita yang didapat dan diadukan itu termasuk fakta ataupun hoaks dari kebenaran informasi yang saya terima".

Informan 1 menjelaskan seluruh anggota tim Jalahoaks berpartisipasi dengan baik dalam melangsungkan kegiatan komunikasi advokasi yang dilakukan, "Kalau berbicara partisipasi yang pasti tim kita melaksanakan tugas dan perannya masing-masing sesuai dengan fungsi kerjanya".

Aksi yang dilakukan oleh Jalahoaks dalam melakukan advokasi pemberitaan hoaks menurut Informan 1 menjelaskan tentang cara yang dilakukan oleh Jalahoaks dalam mempertahankan keberlangsungan kegiatan komunikasi advokasi, "Untuk keberlangsungan di kita yang pertama kita tetap melaksanakan tugas kerja masing-masing. Kita terus melakukan kampanye, advokasi, dan menyosialisasikan tentang kanal-kanal Jalahoaks ini".
Informan 2 juga mengungkapkan untuk mempertahankan pengulangan pesan yang disampaikan kepada publik dengan cara, "Kita melakukannya dengan cara rutin memposting di feeds dan story Instagram. Kita tetap mempertahankan kegiatan advokasi dengan cara melalui media sosial dan selalu membagikan postingan atas klarifikasi fakta berita hoaks setiap harinya".

Pada tahap evaluasi, Informan 1 menjelaskan bahwa evaluasi mengenai komunikasi advokasi yang telah dilakukan oleh Jalahoaks berupa laporan kegiatan yang mencakup jumlah hasil dari aduan yang berhasil diklarifikasi, "Untuk evaluasi yang kita jalankan, kita biasanya ada semacam laporan pelaksanaan kegiatan bulanan, bentuknya per triwulan yang dibuat. Kemudian, ada juga laporan tahunan hasil proses klarifikasi yang kita susun. Bentuk evaluasinya dengan melihat laporan yang kita buat tersebut".

Informan 2 menambahkan Jalahoaks selalu rutin mengadakan rapat internal untuk monitoring mengenai klarifikasi pemberitaan hoaks yang telah diadvokasikan, "Biasanya tim Jalahoaks itu ada meeting/rapat rutin setiap satu sampai dua pekan sekali. Tetapi, jika ada yang sifat-sifatnya kondisional, itu bisa dilakukan dengan segera".

Informan 3 juga mengungkapkan gambaran pengalamannya mengenai evaluasi bagi Jalahoaks dalam melakukan kegiatan komunikasi advokasi pemberitaan hoaks, "Untuk evaluasi pengaduan kepada Jalahoaks bisa dibilang sudah bagus, karena admin itu tersendiri sudah terbilang cukup cepat dan responsif dalam menanggapi pengaduan berita lewat direct message $(\mathrm{dm})$ Instagram ataupun Whatsapp".

Kesinambungan adalah tahap terakhir dari proses komunikasi advokasi yang dijalankan. Informan 1 mengungkapkan untuk tetap terus konsisten dalam melakukan komunikasi advokasi, "Dalam hal mempertahankan fungsi advokasi ini, kita selalu melaksanakan proses kerja di Jalahoaks sesuai dengan alur kerja yang sudah kita buat dan disepakati untuk sama-sama dilaksanakan. 
Termasuk dengan melakukan sosialisasi, dll untuk bisa diketahui oleh masyarakat".

Informan 1 menjelaskan komunikasi advokasi yang dilakukan oleh Instagram @Jalahoaks bertujuan untuk mengentaskan permasalahan mengenai maraknya penyebaran berita hoaks yang beredar di masyarakat, "Tujuan jangka panjang kita yang pasti tidak ada lagi isu hoaks di masyarakat. Kalau berbicara mengenai visi ke depannya, harapannya masyarakat bisa melek akan adanya informasi yang benar seperti apa. Bentuknya masyarakat dapat teredukasi dengan baik terhadap adanya informasi yang benar".

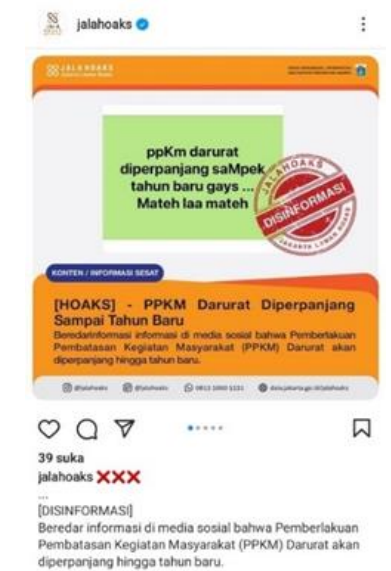

Gambar 2. Hasil Klarifikasi Fakta Aduan Berita Hoaks (Sumber : Instagram @ Jalahoaks, 2021)

Konten utama yang rutin pada Instagram @Jalahoaks adalah postingan hasil dari klarifikasi fakta pemberitaan hoaks yang telah dilaporkan oleh masyarakat dengan ditambahkan referensi sumber informasi yang serupa dari berbagai macam portal media lainnya. Setelah itu, juga diberikan informasi terkait dengan berita yang telah dilaporkan termasuk ke dalam jenis disinformasi apa, serta diberikan juga penjelasan kesimpulan mengenai fakta sebenarnya dari berita hoaks tersebut ke dalam bentuk narasi/caption. Masyarakat yang telah melaporkan pemberitaan hoaks tersebut dapat dengan jelas dan detail untuk mendapatkan hasil dari klarifikasi fakta atas temuan informasinya melalui postingan di media sosial Instagram @Jalahoaks. Publik dapat dengan lengkap dan mudah mendapatkan informasi hoaks yang telah terklarifikasi kebenarannya, dikarenakan hasil dari klarifikasi tersebut disebarluaskan melalui media sosial yang Jalahoaks miliki. Hal tersebut tidak terlepas dari tujuan dan fungsi dari Jalahoaks yang melakukan komunikasi advokasi di Instagram-nya. Hal ini sesuai dengan penelitian Rahmawati et al (2020) terkait dengan informasi mengenai hoaks dapat dipublikasikan melalui media online.

Instagram @Jalahoaks dikelola oleh admin media sosial itu sendiri yang berkewajiban untuk melakukan penerimaan dan pelayanan pengaduan dari masyarakat yang melaporkan aduan berita hoaks melalui direct message $(\mathrm{dm})$ Instagram untuk diteruskan kepada tim Jalahoaks supaya dapat ditindaklanjuti mengenai advokasi pemberitaan hoaks yang disampaikan untuk ditelusuri atas klarifikasi fakta pemberitaan yang ada. Admin Instagram @Jalahoaks dituntut untuk selalu responsif dalam memantau dan melayani pengaduan dari masyarakat. Waktu operasional penerimaan pengaduan pemberitaan hoaks di Instagram @Jalahoaks dilakukan selama 24 jam, hal tersebut ditujukan supaya masyarakat dapat dengan cepat dan bisa dengan kapan saja untuk dapat melakukan advokasi atas informasi hoaks yang didapatkan. Dengan waktu penerimaan pengaduan yang fleksibel dan tidak dibatasi, Jalahoaks berharap banyak masyarakat yang menerima informasi tetapi masih ragu akan kebenarannya untuk dapat segera melaporkan hasil temuannya kepada Jalahoaks. Notoatmodjo (2012) mengungkapkan bahwa advokasi yang dilakukan harus memiliki komitmen dalam menuntaskan permasalahan secara bersama. Dalam hal ini Instagram @Jalahoaks berkomitmen dengan membuka layanan pengaduan pemberitaan hoaks yang dilakukan setiap harinya demi terpenuhinya kebutuhan informasi bagi masyarakat. 


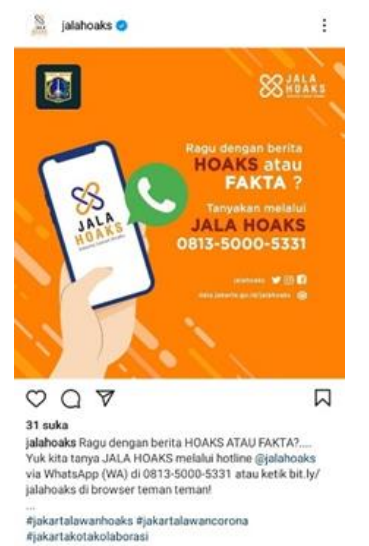

Gambar 3. Layanan Pengaduan Jalahoaks (Sumber : Instagram @ Jalahoaks, 2020)

Informasi yang diberikan oleh Instagram @ Jalahoaks terdiri dari berbagai macam konten yang berhubungaan dengan komunikasi advokasi klarifikasi fakta pemberitaan hoaks yang dijalankan. Konten-konten yang dibuat dan dipublikasikan di Instagram @Jalahoaks bertujuan untuk menginformasikan kepada masyarakat seperti, jumlah laporan klarifikasi aduan yang masuk sehingga terciptanya transparansi kepada publik mengenai apakah Jalahoaks menampung semua laporan aduan yang masuk dan juga berapa tingkat persentase keberhasilan Jalahoaks dalam melakukan klarifikasi. Hal tersebut juga sebagai bahan evaluasi bagi Jalahoaks untuk meningkatkan kinerjanya dalam melangsungkan kegiatan komunikasi advokasi supaya lebih baik lagi di bulan-bulan selanjutnya. Kotler dan Keller (2012) mengungkapkan bahwa media sosial merupakan sarana untuk berbagi gambar dan informasi dengan satu sama lain.

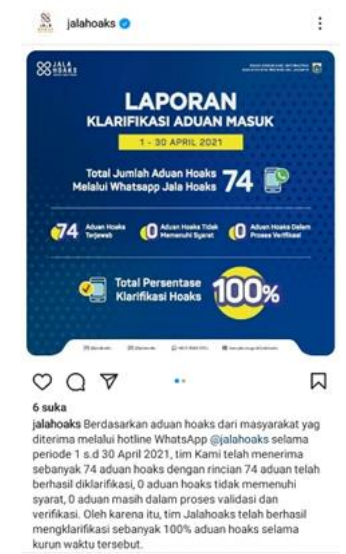

Gambar 4. Laporan Klarifikasi Aduan Masuk (Sumber : Instagram @ Jalahoaks, 2021)

\section{Pembahasan}

Pembahasan dalam penelitian ini adalah pada proses analisis, Jalahoaks selaku badan publik milik Pemprov DKI Jakarta sudah memahami dan menganalisis mengenai permasalahan penyebaran hoaks yang berpotensi mengganggu ketertiban publik sehingga dijalankannya kegiatan komunikasi advokasi tersebut. Hal ini sesuai dengan hasil penelitian Devi (2019) bahwa lembaga/instansi pemerintahan memiliki tanggung jawab dalam memberikan pelayanan kepada masyarakat dalam hal ini mengenai maraknya penyebaran pemberitaan hoaks yang beredar di publik. Perencanaan yang dilakukan oleh Jalahoaks sebelum melakukan komunikasi advokasi adalah dengan mengadakan rapat koordinasi untuk menyusun langkah dan cara yang akan dijalankan. Hal ini sesuai dengan hasil penelitian Rahmi et al (2019) yang mengungkapkan bahwa hal/langkah pertama yang harus dilakukan sebelum pelaksanaan kegiatan advokasi adalah persiapan dan kesiapan dari pihak yang mengadakan advokasi itu sendiri. Analisis yang dilakukan dapat memudahkan Jalahoaks untuk menentukan pemberitaan hoaks yang telah dicek keasliannya termasuk ke dalam kategorisasi disinformasi yang mana. Dibutuhkannya kemampuan dalam memahami dan membedakan mana yang informasi fakta dan mana yang informasi hoaks (Batoebara et al, 2020). Jalahoaks melakukan pencarian dan penelusuran atas informasi yang akurat kepada sumber utama untuk menunjang komunikasi advokasi. Kegiatan advokasi bertujuan untuk mencarikan solusi atas suatu permasalahan (Servaes dan Malikhao, 2012). Jalahoaks sudah memahami dan menganalisis mengenai permasalahan maraknya penyebaran pemberitaan hoaks yang terjadi di masyarakat. Pemerintah yang memahami mengenai masalah yang ada di publik memiliki tujuan untuk menuntaskan terhadap isu-isu yang ada secara bersama (Notoatmodjo, 2012). Rencana yang dilakukan oleh Jalahoaks supaya masyarakat tidak ragu untuk melakukan advokasi dengan cara melakukan literasi digital dengan 
menggunakan pesan komunikasi persuasif. Penggunaan media sosial sebagai sarana komunikasi advokasi sudah dianalisis oleh Jalahoaks supaya memiliki jangkauan yang luas untuk masyarakat. Jalahoaks memilih penggunaan Instagram dalam melakukan komunikasi advokasi berdasarkan hasil analisis survei. Hasil penelitian Simamora (2017) mengungkapkan bahwa media sosial berperan aktif dalam memperlebar jangkauan pemanfaatan untuk keperluan kegiatan advokasi. Pelapor sudah mencari tahu dan analisis terlebih dahulu tentang latar belakang dari kanal Jalahoaks sehingga tidak ragu akan fungsi, tujuan, dan kredibilitasnya dalam melakukan pelayanan komunikasi advokasi pemberitaan.

Pada proses strategi, Jalahoaks selalu berusaha untuk menerima semua pengaduan pemberitaan hoaks yang dilaporkan oleh masyarakat. Advokasi memerlukan aksi strategis yang dapat bermanfaat bagi masyarakat (Reyes, 1997). Fokus pada tujuan khusus dari permasalahan yang ada merupakan strategi yang dilakukan untuk menjalankan setiap kegiatan komunikasi advokasi. Advokasi dilakukan dengan bertujuan mencarikan solusi atas suatu permasalahan (Servaes dan Malikhao, 2012). Jalahoaks juga bertujuan untuk meliterasi dan mengedukasi masyarakat demi mengentaskan permasalahan sosial maraknya penyebaran hoaks.

Pada proses mobilisasi, kegiatan komunikasi advokasi yang dijalankan oleh Instagram @Jalahoaks diperkuat dengan mengandalkan konten-konten yang dibuat dan dipublikasikan di media sosial yang sifatnya komunikasi satu arah. Hal ini sesuai dengan penelitian Rahmi et al (2019) bahwa dalam melakukan komunikasi advokasi yang persuasif harus ditekankan pada pesan yang akan disampaikan. Pemberian sumber-sumber yang relevan dan narasi penjelasan merupakan mobilisasi yang dilakukan Jalahoaks. Adanya partisipasi dari instansi pemerintah maupun media lainnya dalam memobilisasi kegiatan komunikasi advokasi yang dilakukan oleh Jalahoaks. Komunikasi advokasi yang dijalankan oleh Instagram @ Jalahoaks memberikan dampak positif bagi masyarakat dan juga pembuat kebijakan itu sendiri. Hasil penelitian Basuki et al (2018) mengungkapkan bahwa proses komunikasi advokasi yang dilakukan dapat berpengaruh positif pada mobilisasi sosial. Mobilisasi yang dilakukan oleh Jalahoaks harus membutuhkan dukungan penuh dan keterlibatan dari semua anggotanya supaya dapat memperkuat komunikasi advokasi yang dilakukan. Pelapor mengungkapkan mendapatkan manfaat positif setelah melakukan advokasi pemberitaan hoaks kepada Jalahoaks. Advokasi yang dilakukan ditujukan supaya dapat bermanfaat bagi masyarakat (Reyes, 1997).

Pada proses aksi, Jalahoaks bekerja dengan mengikuti alur mekanisme bagan penerimaan pengaduan pemberitaan hoaks yang telah dibuat. Advokasi yang dilakukan harus mendapat dukungan dari mekanisme dan prosedur kerja yang jelas sehingga program tersebut dapat berjalan dengan baik (Notoatmodjo, 2012). Instagram @Jalahoaks menjaga keberlangsungan kegiatan komunikasi advokasi dengan senantiasa melaksanakan dan mempertahankan aksi-aksi dalam menerima dan melakukan proses klarifikasi fakta terhadap pemberitaan hoaks yang masuk. Rutin melakukan posting konten mengenai pemberitaan hoaks yang sudah terklarifikasi faktanya di Instagram setiap harinya merupakan cara dalam aksi yang dilakukan Jalahoaks. Aksi komunikasi advokasi yang dijalankan bertujuan untuk mendapat perhatian dari isu yang ada oleh masyarakat. Penggunaan alat bantu yang kredibel dipakai untuk memperlancar aksi komunikasi advokasi yang dijalankan oleh Jalahoaks. Hal yang membuat pelapor melakukan advokasi kepada Jalahoaks adalah isi narasi dari informasi yang ia laporkan tersebut lebih ke arah provokatif. Hasil penelitian Juditha (2018) mengungkapkan bahwa dalam mengantisipasi penyebaran hoaks masyarakat dapat melakukan literasi terlebih dahulu. Pelapor juga memberikan gambaran pengalamannya dalam melakukan advokasi pemberitaan hoaks kepada Jalahoaks bahwa 
proses dan alur yang dilalui dalam melaporkan temuan berita hoaks untuk diklarifikasikan faktanya cukup mudah dijalankan dan terbilang cepat responnya.

Pada proses evaluasi, usaha komunikasi advokasi yang dilakukan oleh Jalahoaks dievaluasi dengan cara dibuatkannya laporan pelaksanaan kegiatan komunikasi advokasi yang sudah dijalankan. hasil penelitian Rahmi et al (2019) terkait dengan evaluasi merupakan salah satu tahapan dalam menunjang kegiatan komunikasi advokasi yang persuasif. Jalahoaks melakukan sosialisasi kepada masyarakat atas hasil evaluasi dari komunikasi advokasi yang sudah dijalankan dengan memanfaatkan media sosial yang dimilikinya. Menyosialisasikan program kegiatan advokasi dapat dilakukan supaya mendapat dukungan dari masyarakat (Notoatmodjo, 2012). Jalahoaks juga melakukan monitoring evaluasi atas hasil capaian dari komunikasi advokasi yang dilakukan. Pelapor memberikan evaluasi atas usaha komunikasi advokasi yang dilakukan oleh Jalahoaks, pelapor menilai bahwa kinerja Jalahoaks dalam melayani pengaduan pemberitaan hoaks dari masyarakat sudah cukup bagus.

Kesinambungan adalah proses terakhir dari komunikasi advokasi, komunikasi advokasi yang dijalankan harus berlangsung secara terus menerus serta mempertahankan fungsi yang ada. Admin media sosial Instagram @ Jalahoaks bertugas untuk melakukan pemantauan atas perubahan yang terjadi di masyarakat setelah dilakukannya komunikasi advokasi. Upaya yang dilakukan oleh Jalahoaks untuk tetap mempertahankan fungsi keberlangsungan kegiatan komunikasi advokasi klarifikasi fakta pemberitaan hoaks supaya masyarakat tetap bisa mengikuti dan mengetahui aktivitas yang dilakukan adalah dengan selalu aktif di Instagram untuk mempublikasikan konten informasi. Hasil penelitian Rahmawati et al (2020) menunjukkan untuk tetap mempertahankan keberlangsungan advokasi adalah dengan cara mempublikasikan informasi kegiatannya melalui media online. Jalahoaks memiliki tujuan jangka panjang yang ingin dicapai dari adanya kegiatan komunikasi advokasi yang dijalankan untuk mengentaskan permasalahan hoaks yang terjadi di lingkup DKI Jakarta yang berpotensi dapat merugikan masyarakat. Pengadvokasian memiliki tujuan untuk perubahan sosial (Tufte, 2012). Dalam memantau dan mengetahui atas hasil klarifikasi fakta mengenai pemberitaan hoaks yang telah diadukan kepada Jalahoaks dapat dilihat melalui Instagram @ Jalahoaks.

\section{SIMPULAN}

Proses komunikasi advokasi yang dilakukan oleh Instagram @Jalahoaks Diskominfotik Pemprov DKI Jakarta adalah berdasarkan analisis, strategi, mobilisasi, aksi, evaluasi, dan kesinambungan. Analisis yang dilakukan melalui rapat koordinasi internal untuk merencanakan langkah yang akan dipilih untuk dijalankan dan cara yang akan dilakukan pada saat melangsungkan kegiatan komunikasi advokasi klarifikasi fakta pemberitaan hoaks. Strategi yang dilakukan adalah dengan selalu berusaha memantau dan melakukan klarifikasi fakta pemberitaan hoaks dari laporan masyarakat, memberikan pelayanan yang terbaik, serta berfokus pada mengentaskan permasalahan maraknya peredaran berita hoaks yang terjadi di publik. Mobilisasi atas komunikasi advokasi yang dilakukan Jalahoaks diperkuat dengan materi dan pesan pendukung yang disampaikan kepada masyarakat seperti, publikasi konten di Instagram yang menarik dan penggunaan sumber referensi yang jelas serta kredibel dalam klarifikasi berita hoaks sehingga komunikasi advokasi yang dilakukan dapat bermanfaat bagi publik dan membuat semakin banyak masyarakat yang berpartisipasi. Aksi yang dilakukan dalam komunikasi advokasi mengacu pada alur kerja yang telah ditetapkan demi mempertahankan keberlangsungnya serta penggunaan media sosial juga dimaksimalkan untuk menunjang aksi komunikasi advokasi yang dilakukan Jalahoaks supaya mendapat perhatian dari masyarakat. Usaha komunikasi advokasi yang dilakukan dievaluasi dengan cara pembuatan data laporan hasil klarifikasi yang disosialisasikan kepada masyarakat sehingga 
dapat diketahui publik serta melakukan media monitoring atas hasil berita hoaks yang sudah terklarifikasi. Terakhir, kesinambungan atas komunikasi advokasi yang dilakukan adalah dengan tetap konsisten dalam menjalani dan mempertahankan fungsi yang ada untuk mencapai tujuan jangka panjang yang diharapkan.

\section{DAFTAR PUSTAKA}

Adinda, S., \& Edriana, P. (2019). Pengaruh Media Sosial Instagram @exploremalang Terhadap Minat Berkunjung Followers Ke Suatu Destinasi (Survei Pada Followers @explormalang). Jurnal Administrasi Bisnis, 72(1), 176-183.

Basuki, S., Nani, S., \& Sumaryati. (2018). Gambaran Strategi Advokasi Komunikasi Mobilisasi Sosial Dalam Penanggulangan TB Paru di Puskesmas Kalumata Kota Ternate Tahun 2018. Jurnal Ilmiah Serambi Sehat, 11(2), 23-29.

Batoebara, M., Erni, S., \& Cut, A. (2020). Literasi Media Dalam Menanggulangi Berita Hoaks (Studi Pada Siswa SMKN 5 Medan). Jurnal Warta, 14(1), 34-41. https://doi.org/10.46576/wdw.v14i1.541.

Cangara, H. (2017). Perencanaan \& Strategi Komunikasi. Jakarta: Rajawali Pers.

Christanty, N. (2020). Media Sosial Sebagai Alat Advokasi Publik (Studi Kasus Facebook Info Cegatan Blitar Sebagai Alat Advokasi Kebutuhan Pelayanan Administrasi Kependudukan Masyarakat Kabupaten Blitar Tahun 2018-2020). Jurnal Commercium, 3(1), 20-24.

Devi, N. (2019). Upaya Dinas Komunikasi dan Informatika (Diskominfo) Dalam Mengurangi Penyebaran Berita Bohong (Hoax) Pada Media Online di Samarinda. Ejournal Ilmu Pemerintahan, 7(4), 15531566.

Harley, D. (2008). Common Hoaxes and Chain Letters. San Diego: ESET LLC.

Herawati, N., Aliyah, N., \& Dewi, U. (2019). Implikasi Literasi Media Dalam Mengubah Perilaku Masyarakat Kota Pontianak Terhadap Kabar Bohong. Jurnal
Komunikasi dan Media, 3(2), 102-120. https://doi.org/10.33884/commed.v3i2.92 1.

Juditha, C. (2018). Interaksi Komunikasi Hoax di Media Sosial Serta Antisipasinya. Jurnal Pekommas, 3(1), 31-44.

Kotler, P., \& Kevin, L. (2012). Marketing Management. Upper Saddle River, New Jersey: Pearson Prentice Hall.

Listianingrum, R., Ana, F., \& Weni, A. (2021). Strategi Komunikasi Melalui Media Instagram Dalam Memberikan Informasi Kepada Mahasiswa. Jurnal Pustaka Komunikasi, 4(1), 11-23. https://doi.org/10.32509/pustakom.v4i1.13 $\underline{09}$.

Munzaimah, M., \& Fatma, W. (2020). Analisis Penggunaan Media Sosial dan Penyebaran Hoax di Kota Medan. Jurnal Simbolika: Research and Learning in Communication Study, 6(1), 11-22. https://doi.org/10.31289/simbollika.v6i1.2 937.

Mustikaningsih, W. (2016). Implikasi Petisi Online Terhadap Advokasi Kebijakan Publik Tentang RUU Pilkada Langsung 2014-2015 (Studi Kasus Platform Digital Change.org). Jurnal Review Politik, 1-19.

Neuman, W. (2013). Metodologi Penelitian Sosial: Pendekatan Kualitatif dan Kuantitatif. Jakarta: PT Indeks.

Nugraha, M. (2019). Hoax di Media Sosial Facebook: Antara Edukasi dan Propaganda Kepentingan. Jurnal Sosiologi Walisongo, 3(1), 97-108. https://doi.org/10.21580/jsw.2019.3.1.335 $\underline{9}$.

Palupi, M. (2020). Hoax: Pemanfaatannya Sebagai Bahan Edukasi di Era Literasi Digital Dalam Pembentukan Karakter Generasi Muda. Jurnal Skripta, 6(1), 1-12. https://doi.org/10.31316/skripta.v6i1.645.

Rahmawati, Rachmad, K., \& Mawaddah. (2020). Strategi Komunikasi Badan Meteorologi Klimatologi dan Geofisika (BMKG) Aceh Dalam Mengantisipasi Berita Hoax Gempa Aceh. Jurnal Peurawi, 
3(1), http://dx.doi.org/10.22373/jp.v3i1.6532.

Rahmi, F., Hanny, H., \& Iriana, B. (2019). Komunikasi Persuasif Pada Pelaksanaan Advokasi Public Relations. Jurnal Komunikasi Global, 8(2), 116-133. https://doi.org/10.24815/jkg.v8i2.15001.

Simamora, R. (2018). Petisi Online Sebagai Alat Advokasi Kebijakan: Studi Kasus Change.org Indonesia Periode 2015-2016. Jurnal Komunikasi Indonesia, 6(1), 57-67. https://doi.org/10.7454/jki.v6i1.8617

Siswoko, K. (2017). Kebijakan Pemerintah Menangkal Penyebaran Berita Palsu atau 'Hoax'. Jurnal Muara Ilmu Sosial, Humaniora, dan Seni, 1(1), 13-19. http://dx.doi.org/10.24912/jmishumsen.v1 i1.330.

Wilkins, K., Thomas, T., \& Rafael, O. (2014). The Handbook of Development Coummication and Social Change. West Sussex, UK: John Wiley \& Sons. Inc.
Yanti, B., \& Farid, R. (2019). Pengaruh Berita Hoaks Terhadap Persepsi Pembaca Media Online (Pemberitaan Ratna Sarumpaet di Media Kumparan). Jurnal Koneksi, 2(2), 233-239. http://dx.doi.org/10.24912/kn.v2i2.3890. Yin, R. (2011). Qualitative Research from Start to Finish. New York: The Guilford Press.

Zainal, M. (2018). Implementasi Advokasi, Komunikasi, Mobilisasi Sosial Dalam Program Pembanguan Bidang Kesehatan. Jurnal Perspektif Komunikasi, 1(3), 1-10. 